\title{
Youth Migration and Labor Constraints in African Agrarian Households ${ }^{1}$
}

Valerie Mueller (Corresponding author)

Arizona State University, International Food Policy Research Institute

School of Politics and Global Studies

Lattie F. Coor Hal, Room 6778

PO Box 873902

Tempe, AZ 85287-3902

USA

Email: Valerie.Mueller.1@asu.edu

Phone:+1 4809659321

Cheryl Doss

Department of International Development

Oxford University

Queen Elizabeth House

3 Mansfield Road

Oxford OX1 3TB

England

Email: cheryl.doss@qeh.ox.ac.uk

Agnes Quisumbing

International Food Policy Research Institute

2033 K Street NW

Washington, DC 20006

USA

Email: a.quisumbing@,cigar.org

Abstract: Using panel data from Ethiopia and Malawi, we investigate how youth migration affects household labor, hired labor demand, and income, and whether these effects vary by migrant sex and destination. Labor shortages arise from the migration of a head's child. However, the migration of the head's sons produces a greater burden, particularly on female heads/spouses (in Ethiopia) and brothers (in Malawi). Gains from migration in the form of increased total net income justify the increased labor efforts in Ethiopia. Weaker evidence suggests households in Malawi substitute hired for migrant family labor at the expense of total household net income. 


\section{Introduction}

As economic transformations occur across the African continent, migrants are drawn toward employment opportunities in alternative rural and urban locations within country (de Brauw et al., 2014) and abroad (Lucas, 2015). A knowledge gap remains regarding whether these employment shifts constrain the allocation of labor among family members who are left behind and if such adjustments jeopardize agricultural productivity. Multiple factors will determine the direction of the migration impacts. The sex and position of the migrant in the household might influence the migration effects, if the division of agricultural labor is oriented along these dimensions and is not substitutable across them (Holden et al., 2001; Doss, 2002; Croppenstedt et al., 2013). In households that become labor-constrained, access to affordable hired labor will determine whether households can overcome the labor constraints arising from the absence of a household member. Finally, the ability of the household to offset the monetary costs of migration and the costs of replacing missing farm labor will additionally depend on the migrant's earning potential at the destination (McKenzie et al., 2010; Beegle et al., 2011; de Brauw et al., 2013a) and the remittances received by the household.

Thus far, the literature has primarily focused on the impact of the migration of the selfidentified head and his or her spouse on the labor supply outcomes of those left behind in Asian households (de Brauw et al., 2008; Lokshin and Glinskaya, 2009; de Brauw et al., 2013b). However, in Africa, migration rates for youth exceed those of adults (Lee and Mueller, 2016). Despite these growing trends in youth migration, there has been little investigation of the effects on the sending family nor whether these effects differ depending on the migrant's sex. We therefore explore how the migration of young men and women affects the intrahousehold allocation of labor, hired labor use, and household income using publicly available panel datasets in Ethiopia and Malawi. 
Ethiopia and Malawi provide interesting contexts to study the implications of youth migration on rural households. First, gender roles in agriculture are markedly different in Ethiopia and Malawi, with a much higher participation rate of adult women in farm agriculture in Malawi. Thus, we hypothesize that migration would have different consequences on farm labor in the two countries, depending on the sex of the migrant. Second, both countries have strong yet distinct historical antecedents of internal migration. ${ }^{2}$ Urbanization and strong investments in infrastructure by the Ethiopian government has attracted migrants into Addis Ababa (Moller, 2012; Pankhurst et al., 2013), while internal migrants in Malawi, in contrast, are drawn predominantly to other rural areas with available land or agricultural wage employment (Potts, 2006). Third, policy reforms specific to each country may underlie diverse patterns of migration. For example, households may favor the spatial reallocation of youth family members in Ethiopia due to the Federal Land Use Law which precludes household heads from migrating out of fear that their land will be expropriated (Bezu and Holden, 2014).

We employ a difference-in-difference matching approach to identify the impact of having at least one child of the household head migrate on changes in the labor supply of youth and adult household members left behind, the use of hired labor, and household net income (Abadie and Imbens, 2008; Busso et al., 2014). Our identification strategy relies on comparing the outcomes of similar individuals residing in two types of households: those in which at least one child of the household head migrated between the baseline and endline survey rounds and those in which no child migrated. We confirm the robustness of our matching estimates by reporting effects using various restrictions on the matching estimator (e.g., number of matches and trimming the sample). We additionally examine the sensitivity of our results to the sex of the migrant child and to whether the destination of the migrant is rural or urban. We find evidence of labor shortages in both contexts, where the migration of a head's child increases the supply of existing family labor onto 
the farm. However, the migration of heads' sons produce a greater burden, particularly on female heads/spouses (in Ethiopia) and the migrants' brothers (in Malawi). The migration gains in the form of increased household net income justify the increased labor efforts in Ethiopia. Households in Malawi compensate for the shortfall in family labor by utilizing hired labor at the expense of household net income.

\section{Background}

Ethiopia and Malawi are landlocked, low-income countries in Eastern and Southern Africa that are heavily dependent on agriculture. The sector accounts for 30\% and 49\% of GDP in Ethiopia and Malawi, respectively. As Africa's second most populous country, Ethiopia has a much larger population, at 91.7 million persons on about one million square kilometers of area, whereas Malawi has 14.5 million inhabitants on 94,080 square kilometers of land (Aguilar et al., 2015; Kilic et al., 2015). Although both countries are characterized by smallholder agriculture, gender roles in agriculture are quite different, not only because of underlying cultural differences, but also because of their respective histories of policy reform.

Ethiopia has extensive agro-ecological and ethnic diversity, with over 85 ethnic groups and the presence of many of the world's major religions (e.g. Webb et al., 1992; Bevan and Pankhurst, 1996; Fafchamps and Quisumbing, 2002). Social norms regarding the status of women vary widely across the country, depending on ethnicity, religion, and type of agriculture. There are examples of “women's crops" such as enset (false banana), which are the primary responsibility of women and are grown in the South. Additionally, women typically care for livestock and control the proceeds from dairying and other livestock by-products. Although women and men have the same legal rights regarding land ownership and inheritance, particularly after the passage of the Family Law in 2000 (Kumar and Quisumbing, 2015), agricultural cultivation is typically centralized under the control of 
the household head, whether male or female (Fafchamps and Quisumbing, 2002). Cultivation practices, however, can affect the division of labor. For example, in parts of Ethiopia that practice plow cultivation, plowing is almost exclusively performed by men, while women are much more involved in weeding, reaping, and winnowing (Pankhurst, 1990). In places with hoe-based shifting cultivation, men and women share agricultural labor more equally (Rahmato, 1991).

In contrast to Ethiopia, Malawi is smaller, in terms of population and land area, and, also, diverse with respect to inheritance and marital residence regimes. In particular, southern Malawi follows matrilineal customs, and, traditionally, women own the land and their spouses use the land of their wives' families. Daughters of these marriages inherit the land. Even within matrilineal groups, there is variation. Some matrilineal groups of Chewa in the Central Region practice virilocal residence after marriage and more men (whether as sons or nephews) gain primary rights to land than is possible among the matrilineal-matrilocal groups (Peters, 1991). Agriculture in Malawi is hoe-based, and men and women farm their own plots, as well as jointly owned- and managed plots. In contrast to Ethiopia, on average, female family labor dominates farming in Malawi (Aguilar et al., 2015; Kilic et al., 2015).

Migration for employment is historically more important in Malawi, in part due to the pull effects of labor shortages in rural Mozambique (Thomas and Inkpen, 2013) and in the South African mines (Dinkelman et al., 2015), whereas the Government of Ethiopia historically limited interregional migration (Pankhurst et al., 2013). In their recent analysis of migration patterns in four African countries, Mueller et al. (2016) find the percent of individuals (ages 15-65) who outmigrate from rural areas annually is much higher in Malawi than in Ethiopia. In both countries, young men and women ages 15-24 migrate at a higher rate than older men and women ages 25-34, 
but the rate of rural-rural migration is much greater for young women than young men (Lee and Mueller, 2016), owing to early age at marriage within these countries.

As young adults leave their homes to marry, to further their education and employment prospects, or to search for their own land, their departure can influence labor allocation within the household, consequentially affecting agricultural production. The absence of a household member can create a labor supply gap, which could force the household to reallocate activities to other household members (who might otherwise attend school) or to reduce production. Remittances from the migrant could generate additional sources of income to offset potential losses in production or to hire additional labor. To understand these potential tradeoffs, we focus on how youth migration affects the allocation of labor in rural households and their agricultural and net income in the short term. $^{3}$

\section{Data}

We exploit two publicly available panel datasets, the Living Standards Measurement StudyIntegrated Surveys on Agriculture in Ethiopia (2011-2, 2013-4) and Malawi (2010-1, 2012-3)

(World Bank, 2016a; b). Approximately 3,200 and 2,000 panel households in Ethiopia and Malawi, respectively, were surveyed in rural areas. ${ }^{4}$ We use these surveys to create three sets of variables: profile of individuals and households at baseline, mobility status at endline, and the changes in the intrahousehold allocation of labor and household net income. We describe the demographics and households of individuals (ages 15 through 65) by their relationship to the household head, sex, and mobility status in Section III.A to motivate the discussion of predominant migration patterns. Since exogenous pull and push factors are a crucial component of the matching analysis, we describe how the relevant variables are constructed from separate datasets in Section III.B. Hired labor and income at the household level are described later in Section V.B. 


\section{A. Individual Profile and Labor Allocations}

We include variables that reflect an individual's earning potential and origin household wealth. An individual's worker profile is described using his or her baseline sex, age, marital status, and education (binary variables for whether the person completed primary school, secondary school, or is missing the education variable; omitted category reflects not having completed either primary or secondary school). Capital endowments are proxied by the change in household's inherited land in acreage $^{5}$ and household size, as well as other baseline housing characteristics less prone to temporal change (i.e., the number of rooms in the house, indicators for housing with durable roofs, durable walls, piped water, and a flush toilet at baseline).

An individual is considered a migrant if he or she was present in the household at baseline, but left the household permanently (i.e., is no longer considered a household member) by endline. ${ }^{6}$ This definition includes both short- and long-distance movers; we have broad categories of the migrant's location. We therefore exploit the information pertaining to whether the migrant relocated to a rural or urban location to analyze how our results may be sensitive to the distance of the migrant from the baseline household. ${ }^{7}$

Our main outcomes of interest are the allocation of labor into agricultural and nonagricultural employment at the extensive and intensive margins. We create a suite of binary variables that indicate the employment status of the individual at baseline and endline over the twelve months preceding the interview: works on farm, works in the nonfarm enterprise ${ }^{8}$, and works in wage labor. These variables are not mutually exclusive; persons can engage in multiple activities at a given time. Additionally, we create labor supply variables to quantify migration effects on the intensive margin of outcomes among those who remain in the original household: the total number of hours spent planting, the total number of hours spent harvesting, and the total hours spent 
working on wage labor. ${ }^{9}$ For all of these outcomes, the frame of reference for the agricultural labor cycle is the main season in Ethiopia (September through March) and both the rainy (November through May) and dimba (May to October) seasons in Malawi. ${ }^{10}$ Table 1 displays the baseline averages of the demographic, wealth, and labor supply variables for various subsamples determined by the individual's relationship to the household head and whether or not they will migrate before the next survey round.

Focusing on the nonmigrant samples, we observe substantive differences between men and women. The largest gender differences are in the time spent planting and harvesting exist in Ethiopia. For example, 10 percent fewer female heads/spouses work on the farm than male heads/spouses. Female heads/spouses also spend 290 and 74 fewer hours planting and harvesting, respectively, than male heads/spouses. These differences persist when comparing daughters and sons. In contrast, there are no differences in the proportion of women and men working on the farm and the total hours spent planting in Malawi. Only one subtle difference exists between the time men and women spend harvesting, which disappears when comparing daughters and sons. Rather, in Malawi, gendered employment distinctions exist on the extensive and intensive margin of the non-farm supply of adult labor.

We next review whether the employment profile of members within the household at baseline differed by whether they stayed or moved before endline. ${ }^{11}$ Distinctions between future movers and nonmovers are more prominent for sons (than daughters) in both countries. Migrant sons have a higher prevalence of completing a secondary education. However, despite higher levels of human capital, sons who move by endline in Ethiopia supplied a greater amount of labor in the agricultural sector at baseline than their nonmigrant counterparts, whereas migrant sons in Malawi tended to diversify into non-agricultural employment. Ethiopian migrant sons spend 83 more hours 
planting at baseline than nonmigrant sons, while in Malawi 9 percent fewer migrant sons are likely to work on the farm. Furthermore, 7 percent more of migrant sons are engaged in the wage labor market at baseline in Malawi, spending 82 more hours working on wage labor.

These preliminary findings suggest two alternative channels through which the migration of sons would influence agricultural production and investments. In both contexts, the labor of sons comprises a significant share of total household labor designated to farming. Therefore, sons' absences may cause agricultural production to contract if access to affordable hired labor is limited. Clearly, we would expect the loss of productive labor to entail greater readjustments in Ethiopian households given their heightened reliance on the agricultural sector.

The second channel through which the migration of sons may influence agricultural production is through their access to additional sources of income that could be reinvested in agriculture. Although migrant sons were less involved in key aspects of agricultural production in Malawi at baseline, their diversification into the non-agricultural sector potentially increased the household's access to auxiliary income to support agricultural production (e.g. agricultural inputs, hired labor). While migration may raise the earning potential of migrant sons, it remains unclear whether the family would immediately benefit from the migration decision through the receipt of remittances. To further understand which of these two channels play a more significant role in each country, it will be crucial to inspect whether households with migrant sons tend to hire more labor to compensate for the loss of a productive family member and the implications on household net income.

B. Migrant Selection and Exogenous Migration Push and Pull Factors

Whether a household participates in migration and who is selected within the household to migrate is often based on the expected household benefits of the person's earnings net the opportunity cost 
of his/her absence. Thus, the migration decision itself, and who is selected to migrate from the household, is likely a non-random process. Both components of the benefit-cost analysis will likely depend on the traits of the individual (e.g., skill transferability) and demographics of the household (e.g., number of working age men and women, whether the household is asset poor or landless). This raises concerns over treating a migration explanatory variable as exogenous in a standard regression framework.

To demonstrate how migrant sons and daughters may differ by individual traits, we compare the statistical differences in the average age, education, and marital status of migrants and nonmigrants in the son and daughter subsamples in Table 1. The differences appear more pronounced among migrant sons (rather than the daughters) of heads who move out of the household. For example, 6 and 10 percent more of the sons of heads who migrate in Ethiopia and Malawi, respectively, completed a secondary education at baseline. In contrast, the educational attainment of daughters at baseline does not appear associated with migration status. Instead, the primary differences between migrant and nonmigrant daughters are their propensities to be married. Because selection into migration within a household is not random, we use a nearest neighbor matching approach to account for the endogeneity of having at least one child of the head migrate from the household.

We use variables that capture baseline wealth and reflect labor market pull and push factors to match each (nonmigrant) individual living in a migrant household with similar (nonmigrant) individuals living in nonmigrant households from the sample. Baseline household size and inherited land are used to match individuals from households facing similar demographic compositions and wealth. Wage growth in the nearest town (city) in Ethiopia (Malawi) is used as a measure of outside employment opportunities driving migration. ${ }^{12}$ Household georeferenced location points in 
conjunction with shapefiles from each country allow for the identification of the nearest town (city) for each individual in our sample. The second and third rounds of the Integrated Household Survey (2004-5, 2010-1), collected by Malawi’s National Statistical Office, are utilized to compute the mean wage growth of ganyu (casual) labor for all cities in Malawi. In Ethiopia, we construct the wage growth variables based on the Country and Regional Level Consumer Price Indices database (CSA, 2013a). ${ }^{13}$ The data allow us to measure the percentage increase in wages from the casual labor wage market in 2009 and 2011.

We integrate two additional variables reflecting push factors. First, we use the share of households that left the community before the baseline survey, as extrapolated from the baseline LSMS-ISA community questionnaires, to proxy mobility costs. We add an interaction between the migrant networks and wage growth variables to capture the benefits of migration, net of mobility costs. Second, we include the coefficient of variation of rainfall to detect evidence of ex ante risk management in the form of the migration (Dillon et al., 2011) or off-farm employment (Rose, 2001) of household members. The historical mean and standard deviation of rainfall parameters were computed using a secondary resource for climate data online (CHIRPS, 2015).

\section{Empirical Strategy}

We estimate the effect of having a child of the household head migrate on changes in the labor of individual non-migrant member $i$ in household $h$ in village $j$ using the following difference-indifference regression:

$$
\Delta Y_{i h j}=\alpha+\beta_{H} \boldsymbol{H}_{i}+\beta_{D} \boldsymbol{W}_{h}+\beta_{M} M_{h}+\beta_{X} \Delta \boldsymbol{X}_{h}+v_{j}+t_{j}+\Delta \varepsilon_{i h j}
$$

where $\Delta Y$ refers to the change in the individual's outcome; $H$ is a vector of baseline characteristics that reflect an individual's productivity and human capital (age and indicators for completed 
primary school, completed secondary school, missing education, married, sex, and relationship to the household head); $W$ includes variables that represent initial household wealth (the number of rooms in the house, indicators for housing with durable roofs, durable walls, piped water, and a flush toilet at baseline); $M$ is a binary variable which indicates whether the household has a migrant child; and $\Delta X$ captures changes in household human and physical capital (change in household size and inherited land). District fixed effects $v_{j}$ control for time invariant cultural, economic and geographic characteristics, such as social norms dictating gender-differentiation in labor activities and labor market structure, which can influence the allocation of labor in the household. Separate regressions are estimated for the pooled sample, male heads/spouses, female heads/spouses, daughters, and sons. Summary statistics of the explanatory variables, outcomes, and matching variables by sample are presented in Table A.1. Standard errors are clustered by enumeration area, accounting for the correlation of outcomes within a geographic area.

While the difference-in-difference model reduces bias arising from time invariant characteristics, a remaining threat to the identification of migration impacts is the non-random selection of family members to migrate for marriage, employment, or other reasons. We therefore employ a difference-in-difference nearest neighbor matching approach to account for the endogeneity of the migration outcome (Abadie and Imbens 2008). The procedure enables comparisons of the outcomes of individuals in migrant households with otherwise similar individuals residing in households without migrants. The metric used to characterize individuals from migrant and nonmigrant households as similar is based on the Euclidean distance of the vector of covariates applied in the matching exercise. Individuals residing in migrant households are compared to individuals in households without migrants that have the lowest difference in the distance-metric value. We use the nearest neighbor algorithm rather than other metrics, such as the propensity score, because it is nonparametric (and not limited by smaller sample sizes), the 
analytical standard errors have been derived (Abadie and Imbens, 2008), and is easy to implement with more complicated sampling frames. ${ }^{14}$ Balancing tests indicate the matching approach performs reasonably well in assigning individuals in households without youth migrants to individuals in households with youth migrants to estimate the migration impacts (Tables A.2 and A.3). To reduce any bias caused from inexact matching, we adjust the results using an additional regression-based procedure (Abadie et al., 2004).

The quality of the matching approach relies on the strength of the variables as migration determinants, in addition to their value in producing quality matches. To validate the use of the matching instruments, we report estimates of the marginal effects and standard errors in a probit regression quantifying the relationships between the individuals in a household having at least one child migrant and the variables used in the matching exercise in Tables A.4 and A.5. For simplicity, we pool the nonmigrant sons, daughters, and female and male heads/spouses and use separate specifications for Ethiopia and Malawi. The regression results indicate that household wealth (with the exception of having a flush toilet) discourages child migration in Ethiopia. In contrast, risk and employment opportunities net of mobility costs encourage the migration of the head's children in Malawi. In both countries, household size increases the migration of the head's children, which is not surprising given the growing land scarcity in these areas.

We verify that the main results are not affected by various parameters in the matching exercise. First, we compare our main results, based on matching individuals from migrant households each with two individuals from nonmigrant households, with estimates using one and four numbers of matches. While increasing the number of matches increases the sample size and therefore the ability to detect significance, it could bias the estimate if the additional matches are more dissimilar. We further show that the results are insensitive to trimming the sample by 1 percent at the top and bottom of the distribution. When graphing predicted propensities to migrate 
using the covariates of interest, we find overlap in the distributions varies at the tail ends (Figures A.1 and A.2). Thus, trimming the sample can improve the quality of the matches by ensuring the pool of nonmigrants is more comparable to the pool of migrants to be matched.

Our main results report the impact of having at least one migrant child on the outcomes of members left behind using OLS and difference-in-difference nearest neighbor matching. However, accounting for the sex of the migrant child and the destination of migrant might enhance the interpretation of the results, particularly if divisions of labor are gendered and the barriers to substitute labor differ by the earning potential of the migrant. We therefore also provide OLS and difference-in-difference nearest neighbor matching, replacing $M$ with a binary variable which indicates whether the household has a migrant son, migrant daughter, and rural-urban child migrant. ${ }^{15}$

\section{Results}

\section{A. Impacts of Youth Migration on Labor}

Tables 2 and 3 display the OLS and matching estimates of the impacts of having at least one migrant child of the household head on the intrahousehold allocation of nonmigrant labor. The Rsquared values indicate that the OLS models provide a reasonable goodness of fit for the pooled sample in Ethiopia, where they explain 10 to 39 percent of the variation in the outcomes compared to 2 to 9 percent of the variation in outcomes in Malawi. While both OLS and matching approaches provide similar impact magnitudes (with a few exceptions), the precision in the estimate varies by approach. We can provide robust estimates only for one outcome in Malawi. When a head's child migrates, a son's likelihood of working on the farm increases by 17 to 19 percentage points. The $\mathrm{F}$ statistic value of 4.19 from a pooled OLS regression that tests for the equality of migration impacts 
across daughters, sons, male heads/spouses, and female heads/spouses indicates we can reject that the effects are equal across family members.

One explanation for the lack of precision in our estimates is the existence of various motives for migration. The employment migration dominated by males in Africa (Mueller et al., 2016) can result in remittance receipts for the household, which may relax liquidity constraints and allow them to hire labor, expand, or diversify investments. Moreover, the dominant pattern of migration in many African countries is rural to rural, often with short-distance travel (Mueller et al., 2016), which may allow absent household members to continue to work on the farm with minimal disruption. To understand better these nuances and how they might influence our interpretation of results, we first provide figures that distinguish the migration effects by the sex of the household head's child, and by whether the destination of the migrant is urban. ${ }^{16}$

By focusing on the migration of the head's sons, we can state more conclusively how the allocation of labor is affected. ${ }^{17}$ In Ethiopia, the absence of a head's son induces an overall 7 percentage point increase in the likelihood that family members work on the farm. Adult women (heads/spouses) compensate for the shortfall in labor (Table 4); 7 to 9 percent of female heads/spouses are more likely to work on the farm. However, on the intensive margin, sons devote a greater number of hours to harvesting (61 to 87 hours). While we can conclusively assert that all family members, especially adult women, are spending more time on the farm due to the departure of a son, the F tests suggest we cannot reject that the increased efforts of sons on the intensive margin are equal to the other members in the family (F statistic=0.80). As in Ethiopia, sons in Malawi are picking up the slack for the departure of their brothers, however, they do so by spending more hours planting rather than harvesting (40 to 49 hours) (Table 5). ${ }^{18}$ 
In contrast, the departure of young women in the household appears to affect labor allocations only for the households in Malawi, as the estimates in Tables 6 and 7 suggest. A greater percentage of household members are required to work on the farm, especially sons and daughters. Specifically, we witness a 15 to 18 percentage point increase in sons working on the farm and a 27 to 32 percentage point increase in daughters working on the farm. An F statistic value of 5.43 allows us to reject that the effects are equal. In a context where women at all ages play a more unequivocal role in agriculture, other family members are, thus, equally substitutable for the loss of family farm labor.

Lastly, we compare the effects of having a rural-urban migrant child on the allocation of labor among the remaining household members (Tables 8 and 9). Having a child of the household move to an urban location may impose greater demands on sons' time during the harvesting period in Ethiopia (Table 9), but we cannot reject that those effects are statistically different than the effects on others in the family ( $F$ statistic $=0.25$ ). Having a rural-urban youth migrant in a household in rural Malawi continues to increase the demand on all household members to work on the farm (Table 9). It, also, increases the demand for daughters to spend time planting, and decreases overall engagement in enterprise activities.

\section{B. Mechanisms}

We have largely demonstrated that the loss of a family member imposes additional burdens on family members, and the nature of who is affected depends on the gender and destination of the migrant. However, our interpretations have, thus far, ignored the potential for households to use hired labor, which offers the opportunity to overcome labor constraints but at an additional cost to production. In fact, the summary statistics in Table 10 allude to the importance of hired labor in these countries, where 19 and 37 percent of households in Ethiopia and Malawi, respectively, 
contracted at least one person to assist on the farm at baseline. We therefore use the previous OLS and matching specifications to observe whether having a migrant child, migrant son, migrant daughter, and rural-urban migrant child changes the use of hired labor over time at the household level. This specifically involves re-estimating (1) using the change in the use of hired labor as an outcome defined at the household level and dropping individual level covariates. The results in column (1) of Table 10 indicate that there are no changes in the use of hired labor in Ethiopia in response to having at least one migrant child in the household. In contrast, when the household has a migrant child in Malawi, whether it be a migrant son or daughter, the percentage of households that hire at least one employee on the farm increases on the order of 0.17 to 0.30 percentage points (matching estimates, column (4)).

We finally explore whether the migration-induced labor constraints in Ethiopia or additional hired labor costs to production in Malawi cause an overall contraction in agricultural and total net household income. ${ }^{19}$ From the results in Table 10, there is no strong indication that the migration of heads' children compromises agricultural or overall household income. In Ethiopia, there are clear positive benefits of having a migrant son or rural-urban migrant on overall household income, which potentially justifies the increased efforts of others on the farm. In Malawi, weaker evidence suggests the departure of a migrant son can harm agricultural (matching $p$-value $=0.01$ ) and total (OLS p-value $=0.11$ and matching $p$-value $=0.14)$ net income at the household level.

\section{Conclusion}

Policy makers in Africa are increasingly expressing concern about the future of agriculture. While the processes of structural transformation typically involve people moving out of agriculture, the specifics of this process may determine who gains and who loses. In some areas, when men migrate out of rural areas, women remain on the farms and we observe what is often called the feminization of agriculture. In other areas, including Malawi and Ethiopia, youth leave their agricultural 
households and migrate either to other rural areas or to urban centers. While migration may have long term effects on the agricultural sector, in this paper, we have considered the short-term impacts on rural households when a child of the head migrates. Since most of the literature focuses on the impact on the youth migrant him or herself, this paper contributes by analyzing the impacts on their origin household, particularly the labor allocations, hired labor, and income (which consequentially affects agricultural investments in the long term).

It is often assumed that there is excess labor in low productivity smallholder agriculture. Yet, we observe sons contribute to both agricultural and nonagricultural activities and when they migrate, some of their labor is replaced by other members of the household. In Ethiopia, the women who are heads/spouses may begin working on the farm when a son leaves. Similarly, in Malawi, when a son of the head migrates, his brothers work more on the farm. When daughters migrate, the demand for farm labor of sons and daughters increases at the extensive margin but only for the case of Malawi. Adjustments in hired labor in response to the migration of sons in Malawi (alone) illustrate a shortfall in on-farm labor. Only in Malawi is labor hired to compensate for the loss in labor of the migrating youth.

Two potential mechanisms could explain the observed impacts of youth migration on household labor constraints and welfare. One hypothesis is that the increased efforts of female heads/spouses in Ethiopian households and the costs of hired labor in Malawian households may serve as imperfect substitutes for the labor of migrant sons, jeopardizing overall agricultural income. A second hypothesis is that the additional income available to the household from the migrant may be used to adopt new technologies or practices that mediate the losses attributable to the loss of migrant labor, such as the use of animal traction. Our findings support the former hypothesis in Malawi but not in Ethiopia. Specifically, our nearest neighbor matching estimate indicates losses in agricultural net income on the order of 30 percent among households having at 
least one migrant son in Malawi. In contrast, gains from migration in the form of increased total net income justify the increased labor efforts in Ethiopia.

This analysis considers only the short run effects of youth migration. Although the survey rounds are two years apart, the child may have migrated in the second year, with relatively little time for the household to adjust other than the immediate change in labor allocations. In Malawi, there is already marginally significant evidence that a failure to compensate for the loss of a migrant son to the household may lead to losses in agricultural and total household profit. Thus, youth migration may have a broader impact on household outcomes than is captured within this short-term interval; after another round or two of data collection, after further readjustments have occurred, clearer patterns are more likely to emerge. 
Table 1: Baseline Characteristics and Labor Outcomes of Household Members (Means)

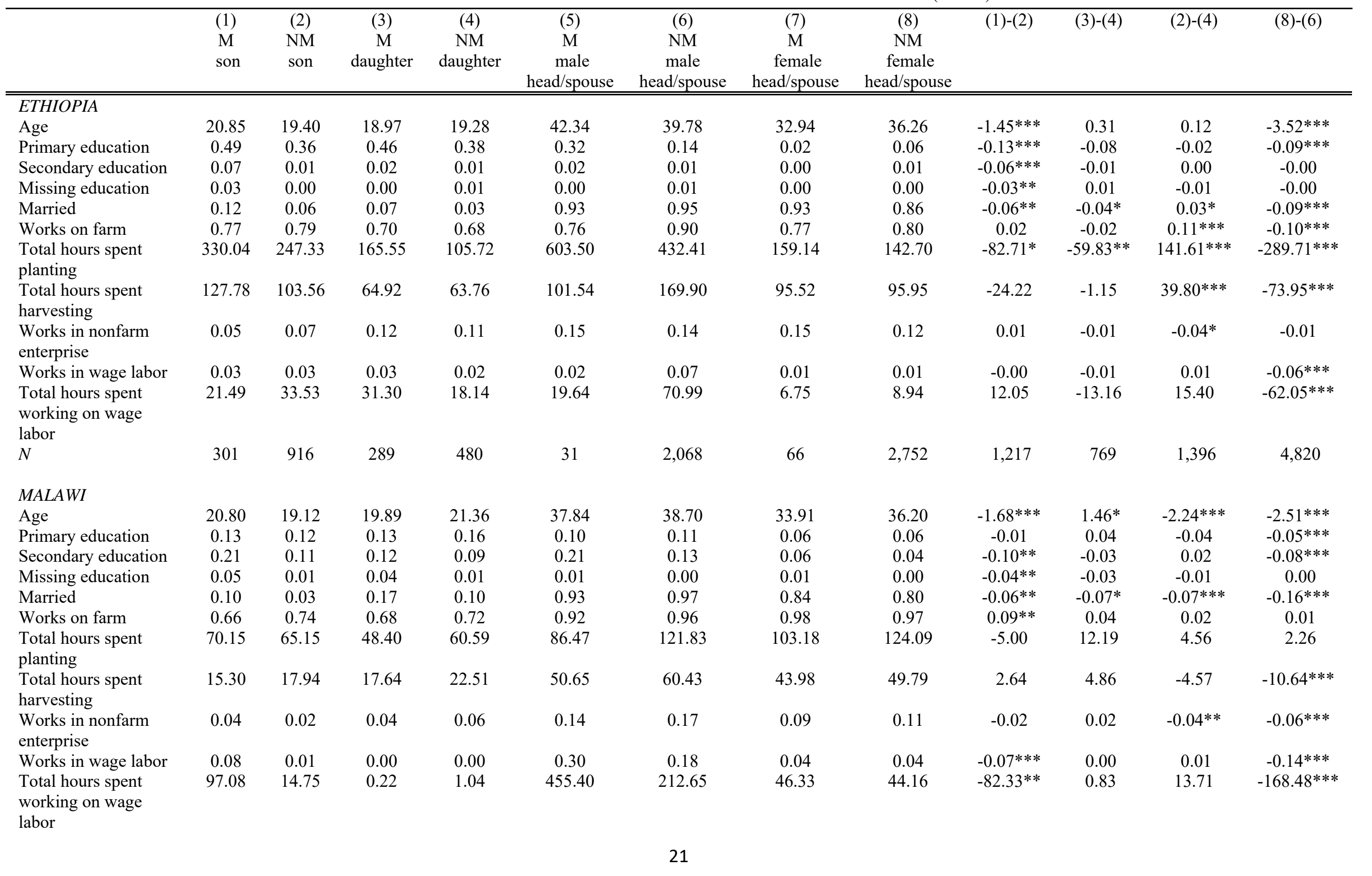


Table 2: Impacts of the Migration of a Head's Child, OLS and Matching Estimates for Ethiopia

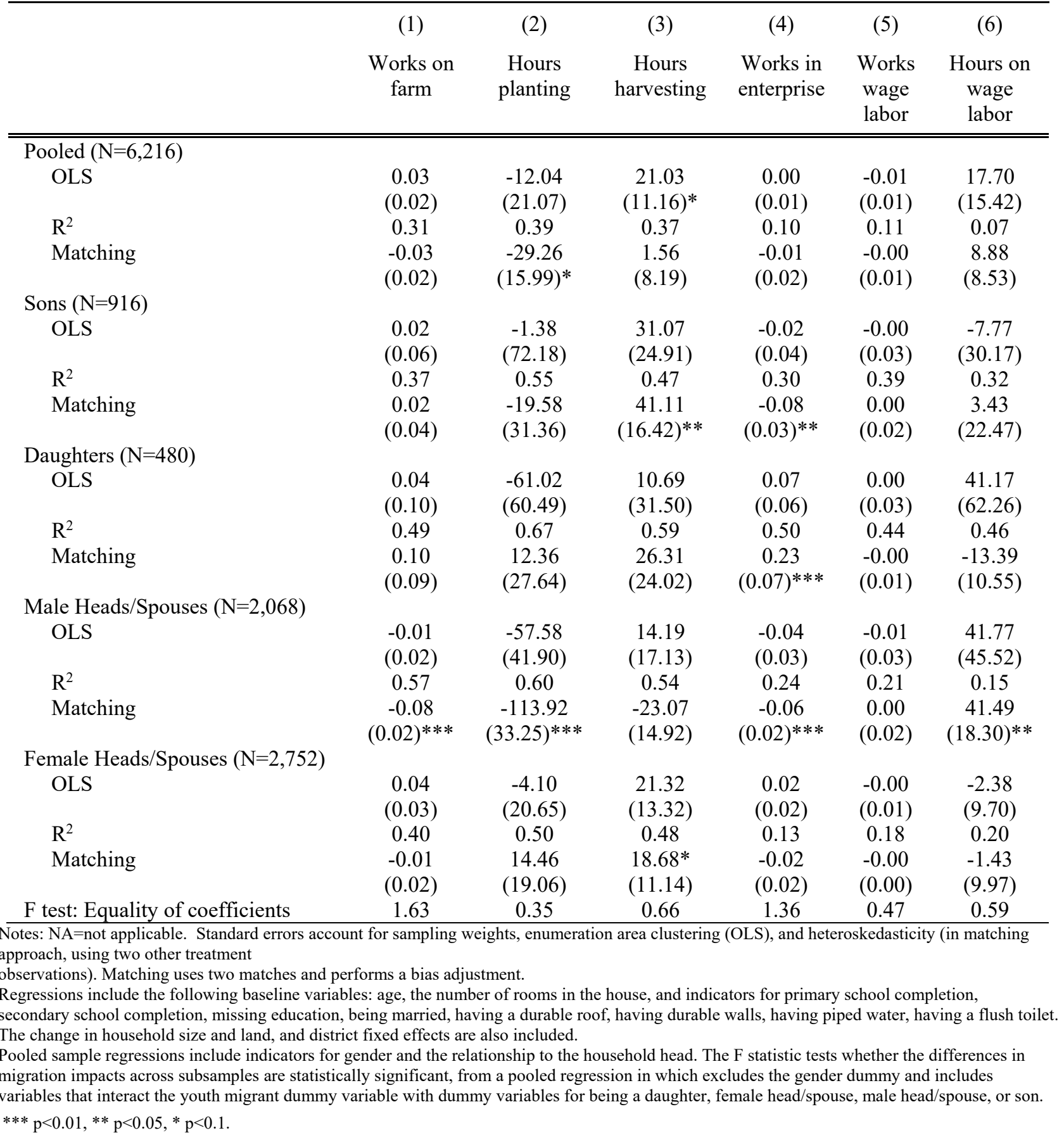


Table 3: Impacts of the Migration of a Head's Child, OLS and Matching Estimates for Malawi

\begin{tabular}{|c|c|c|c|c|c|c|}
\hline & (1) & (2) & (3) & (4) & (5) & (6) \\
\hline & $\begin{array}{l}\text { Works on } \\
\text { farm }\end{array}$ & $\begin{array}{l}\text { Hours } \\
\text { planting }\end{array}$ & $\begin{array}{c}\text { Hours } \\
\text { harvesting }\end{array}$ & $\begin{array}{l}\text { Works in } \\
\text { enterprise }\end{array}$ & $\begin{array}{l}\text { Works } \\
\text { wage } \\
\text { labor }\end{array}$ & $\begin{array}{c}\text { Hours on } \\
\text { wage } \\
\text { labor }\end{array}$ \\
\hline \multicolumn{7}{|l|}{ Pooled $(\mathrm{N}=3,643)$} \\
\hline OLS & $\begin{array}{c}0.05 \\
(0.03)\end{array}$ & $\begin{array}{c}28.75 \\
(11.18)^{* *}\end{array}$ & $\begin{array}{l}13.21 \\
(9.86)\end{array}$ & $\begin{array}{c}0.03 \\
(0.03)\end{array}$ & $\begin{array}{c}0.01 \\
(0.01)\end{array}$ & $\begin{array}{c}4.23 \\
(19.73)\end{array}$ \\
\hline $\mathrm{R}^{2}$ & 0.06 & 0.09 & 0.05 & 0.03 & 0.03 & 0.02 \\
\hline Matching & $\begin{array}{c}0.09 \\
(0.02)\end{array}$ & $\begin{array}{c}-13.19 \\
(5.37)^{* *}\end{array}$ & $\begin{array}{c}11.18 \\
(3.44)^{* *}\end{array}$ & $\begin{array}{c}0.00 \\
(0.02)\end{array}$ & $\begin{array}{l}-0.00 \\
(0.01)\end{array}$ & $\begin{array}{l}-21.66 \\
(20.34)\end{array}$ \\
\hline \multicolumn{7}{|l|}{ Sons $(\mathrm{N}=549)$} \\
\hline OLS & $\begin{array}{c}0.17 \\
(0.07)^{* *}\end{array}$ & $\begin{array}{c}38.56 \\
(16.70)^{* *}\end{array}$ & $\begin{array}{c}9.86 \\
(14.48)\end{array}$ & $\begin{array}{c}0.09 \\
(0.03)^{* * *}\end{array}$ & $\begin{array}{c}0.01 \\
(0.03)\end{array}$ & $\begin{array}{c}16.74 \\
(36.06)\end{array}$ \\
\hline $\mathrm{R}^{2}$ & 0.14 & 0.19 & 0.14 & 0.11 & 0.18 & 0.24 \\
\hline Matching & $\begin{array}{c}0.19 \\
(0.06)^{* * *}\end{array}$ & $\begin{array}{c}7.14 \\
(12.24)\end{array}$ & $\begin{array}{c}1.06 \\
(8.70)\end{array}$ & $\begin{array}{c}0.01 \\
(0.04)\end{array}$ & $\begin{array}{c}0.07 \\
(0.03)^{* *}\end{array}$ & $\begin{array}{c}-2.56 \\
(52.93)\end{array}$ \\
\hline \multicolumn{7}{|l|}{ Daughters $(\mathrm{N}=394)$} \\
\hline OLS & $\begin{array}{c}0.20 \\
(0.10)^{* *}\end{array}$ & $\begin{array}{c}25.35 \\
(14.87)^{*}\end{array}$ & $\begin{array}{c}-4.94 \\
(16.53)\end{array}$ & $\begin{array}{l}-0.06 \\
(0.07)\end{array}$ & $\begin{array}{c}0.02 \\
(0.01)\end{array}$ & $\begin{array}{c}17.91 \\
(14.43)\end{array}$ \\
\hline $\mathrm{R}^{2}$ & 0.14 & 0.25 & 0.15 & 0.17 & 0.25 & 0.43 \\
\hline Matching & $\begin{array}{c}0.14 \\
(0.10)\end{array}$ & $\begin{array}{c}18.28 \\
(13.77)\end{array}$ & $\begin{array}{c}3.41 \\
(12.92)\end{array}$ & $\begin{array}{l}-0.06 \\
(0.04)\end{array}$ & $\begin{array}{c}0.02 \\
(0.01)\end{array}$ & $\begin{array}{c}0.59 \\
(0.42)\end{array}$ \\
\hline \multicolumn{7}{|l|}{ Male Heads/Spouses $N=1,164$ ) } \\
\hline OLS & $\begin{array}{l}-0.04 \\
(0.04)\end{array}$ & $\begin{array}{c}35.91 \\
(18.16)^{* *}\end{array}$ & $\begin{array}{c}17.04 \\
(14.15)\end{array}$ & $\begin{array}{c}0.08 \\
(0.05)^{*}\end{array}$ & $\begin{array}{c}0.00 \\
(0.04)\end{array}$ & $\begin{array}{l}-49.41 \\
(67.89)\end{array}$ \\
\hline $\mathrm{R}^{2}$ & 0.11 & 0.11 & 0.05 & 0.06 & 0.04 & 0.05 \\
\hline Matching & $\begin{array}{l}-0.02 \\
(0.03)\end{array}$ & $\begin{array}{l}-11.87 \\
(14.76)\end{array}$ & $\begin{array}{c}14.66 \\
(11.63)\end{array}$ & $\begin{array}{c}0.06 \\
(0.04)\end{array}$ & $\begin{array}{l}-0.02 \\
(0.03)\end{array}$ & $\begin{array}{l}-55.16 \\
(42.75)\end{array}$ \\
\hline \multicolumn{7}{|c|}{ Female Heads/Spouses $(\mathrm{N}=1,536)$} \\
\hline OLS & $\begin{array}{l}-0.00 \\
(0.03)\end{array}$ & $\begin{array}{c}13.67 \\
(15.02)\end{array}$ & $\begin{array}{c}16.65 \\
(10.64)\end{array}$ & $\begin{array}{c}0.01 \\
(0.04)\end{array}$ & $\begin{array}{l}-0.00 \\
(0.01)\end{array}$ & $\begin{array}{c}45.07 \\
(19.49)^{* *}\end{array}$ \\
\hline $\mathrm{R}^{2}$ & 0.08 & 0.09 & 0.06 & 0.04 & 0.05 & 0.05 \\
\hline Matching & $\begin{array}{l}-0.00 \\
(0.02)\end{array}$ & $\begin{array}{c}-35.92 \\
(10.94)^{* * *}\end{array}$ & $\begin{array}{c}9.36 \\
(7.93)\end{array}$ & $\begin{array}{c}0.02 \\
(0.03)\end{array}$ & $\begin{array}{c}-0.02 \\
(0.01)^{*}\end{array}$ & $\begin{array}{c}0.81 \\
(17.23)\end{array}$ \\
\hline F test: Equality of coefficients & $4.19 * * *$ & $3.03 * *$ & 0.42 & $2.31 *$ & 1.23 & 1.28 \\
\hline
\end{tabular}


Table 4: Impacts of the Migration of a Head's Son, OLS and Matching Estimates for Ethiopia

\begin{tabular}{|c|c|c|c|c|c|c|}
\hline & (1) & (2) & (3) & (4) & $(5)$ & (6) \\
\hline & $\begin{array}{l}\text { Works on } \\
\text { farm }\end{array}$ & $\begin{array}{l}\text { Hours } \\
\text { planting }\end{array}$ & $\begin{array}{c}\text { Hours } \\
\text { harvesting }\end{array}$ & $\begin{array}{l}\text { Works in } \\
\text { enterprise }\end{array}$ & $\begin{array}{l}\text { Works } \\
\text { wage } \\
\text { labor }\end{array}$ & $\begin{array}{c}\text { Hours on } \\
\text { wage labor }\end{array}$ \\
\hline \multicolumn{7}{|l|}{ Pooled $(\mathrm{N}=6,216)$} \\
\hline OLS & $\begin{array}{c}0.07 \\
(0.03)^{* * *}\end{array}$ & $\begin{array}{c}7.95 \\
(23.72)\end{array}$ & $\begin{array}{c}24.35 \\
(12.75)^{*}\end{array}$ & $\begin{array}{c}0.01 \\
(0.03)\end{array}$ & $\begin{array}{c}0.01 \\
(0.01)\end{array}$ & $\begin{array}{c}18.85 \\
(13.99)\end{array}$ \\
\hline $\mathrm{R}^{2}$ & 0.31 & 0.39 & 0.37 & 0.10 & 0.11 & 0.07 \\
\hline Matching & $\begin{array}{c}0.07 \\
(0.03)^{* * *}\end{array}$ & $\begin{array}{c}16.26 \\
(19.88)\end{array}$ & $\begin{array}{c}8.93 \\
(10.26)\end{array}$ & $\begin{array}{l}-0.02 \\
(0.02)\end{array}$ & $\begin{array}{c}0.02 \\
(0.01)^{*}\end{array}$ & $\begin{array}{c}4.63 \\
(9.28)\end{array}$ \\
\hline \multicolumn{7}{|l|}{ Sons $(\mathrm{N}=916)$} \\
\hline OLS & $\begin{array}{c}0.07 \\
(0.08)\end{array}$ & $\begin{array}{c}53.19 \\
(96.13)\end{array}$ & $\begin{array}{c}86.57 \\
(31.36)^{* * *}\end{array}$ & $\begin{array}{l}-0.00 \\
(0.04)\end{array}$ & $\begin{array}{c}0.01 \\
(0.03)\end{array}$ & $\begin{array}{c}-6.62 \\
(36.06)\end{array}$ \\
\hline $\mathrm{R}^{2}$ & 0.37 & 0.55 & 0.47 & 0.30 & 0.39 & 0.32 \\
\hline Matching & $\begin{array}{c}0.10 \\
(0.06)\end{array}$ & $\begin{array}{l}-37.60 \\
(47.85)\end{array}$ & $\begin{array}{c}60.52 \\
(19.95)^{* * * *}\end{array}$ & $\begin{array}{c}-0.08 \\
(0.04)^{*}\end{array}$ & $\begin{array}{l}-0.01 \\
(0.02)\end{array}$ & $\begin{array}{c}-7.26 \\
(26.99)\end{array}$ \\
\hline \multicolumn{7}{|l|}{ Daughters $(\mathrm{N}=480)$} \\
\hline OLS & $\begin{array}{c}0.11 \\
(0.13)\end{array}$ & $\begin{array}{c}-25.89 \\
(76.78)\end{array}$ & $\begin{array}{c}1.43 \\
(33.55)\end{array}$ & $\begin{array}{c}0.19 \\
(0.10)^{*}\end{array}$ & $\begin{array}{l}-0.00 \\
(0.06)\end{array}$ & $\begin{array}{c}89.86 \\
(100.50)\end{array}$ \\
\hline $\mathrm{R}^{2}$ & 0.49 & 0.67 & 0.59 & 0.50 & 0.44 & 0.46 \\
\hline Matching & $\begin{array}{l}0.24^{*} \\
(0.13)\end{array}$ & $\begin{array}{c}3.86 \\
(35.52)\end{array}$ & $\begin{array}{c}33.32 \\
(31.61)\end{array}$ & $\begin{array}{c}0.30 \\
(0.10)^{* * *}\end{array}$ & $\begin{array}{c}0.12 \\
(0.01)^{* *}\end{array}$ & $\begin{array}{c}14.43 \\
(7.45)^{*}\end{array}$ \\
\hline \multicolumn{7}{|l|}{ Male Heads/Spouses $(\mathrm{N}=2,068)$} \\
\hline OLS & $\begin{array}{c}0.01 \\
(0.03)\end{array}$ & $\begin{array}{l}-23.63 \\
(44.23)\end{array}$ & $\begin{array}{c}41.98 \\
(21.50)^{*}\end{array}$ & $\begin{array}{l}-0.00 \\
(0.04)\end{array}$ & $\begin{array}{c}0.04 \\
(0.03)\end{array}$ & $\begin{array}{c}47.15 \\
(41.49)\end{array}$ \\
\hline $\mathrm{R}^{2}$ & 0.57 & 0.60 & 0.54 & 0.24 & 0.21 & 0.15 \\
\hline Matching & $\begin{array}{c}0.01 \\
(0.03)\end{array}$ & $\begin{array}{l}-19.06 \\
(47.40)\end{array}$ & $\begin{array}{l}-27.10 \\
(20.83)\end{array}$ & $\begin{array}{c}-0.07 \\
(0.04)^{*}\end{array}$ & $\begin{array}{c}0.06 \\
(0.03)^{* *}\end{array}$ & $\begin{array}{c}68.11 \\
(22.32)^{* * *}\end{array}$ \\
\hline \multicolumn{7}{|l|}{ Female Heads/Spouses $(\mathrm{N}=2,752)$} \\
\hline OLS & $\begin{array}{c}0.09 \\
(0.04)^{* *}\end{array}$ & $\begin{array}{c}3.05 \\
(25.10)\end{array}$ & $\begin{array}{c}1.46 \\
(16.38)\end{array}$ & $\begin{array}{l}-0.00 \\
(0.04)\end{array}$ & $\begin{array}{l}-0.00 \\
(0.01)\end{array}$ & $\begin{array}{c}-4.91 \\
(10.03)\end{array}$ \\
\hline $\mathrm{R}^{2}$ & 0.40 & 0.50 & 0.48 & 0.13 & 0.18 & 0.20 \\
\hline Matching & $\begin{array}{c}0.07 \\
(0.04)^{*}\end{array}$ & $\begin{array}{c}14.87 \\
(26.02)\end{array}$ & $\begin{array}{c}14.06 \\
(13.73)\end{array}$ & $\begin{array}{l}-0.02 \\
(0.03)\end{array}$ & $\begin{array}{c}0.00 \\
(0.00)^{*}\end{array}$ & $\begin{array}{c}4.12 \\
(15.24)\end{array}$ \\
\hline F test: Equality of coefficients & $2.83 * *$ & 0.29 & 0.80 & 0.64 & 0.55 & 0.69 \\
\hline
\end{tabular}

Notes: $* * * \mathrm{p}<0.01,{ }^{* *} \mathrm{p}<0.05, * \mathrm{p}<0.1$. See Table 2 notes for details on specifications. 
Table 5: Impacts of the Migration of a Head's Son, OLS and Matching Estimates for Malawi

\begin{tabular}{|c|c|c|c|c|c|c|}
\hline & (1) & (2) & (3) & (4) & $(5)$ & (6) \\
\hline & $\begin{array}{l}\text { Works on } \\
\text { farm }\end{array}$ & $\begin{array}{c}\text { Hours } \\
\text { planting }\end{array}$ & $\begin{array}{c}\text { Hours } \\
\text { harvesting }\end{array}$ & $\begin{array}{l}\text { Works in } \\
\text { enterprise }\end{array}$ & $\begin{array}{l}\text { Works } \\
\text { wage } \\
\text { labor }\end{array}$ & $\begin{array}{c}\text { Hours on } \\
\text { wage } \\
\text { labor }\end{array}$ \\
\hline \multicolumn{7}{|l|}{ Pooled $(\mathrm{N}=3,643)$} \\
\hline OLS & $\begin{array}{c}0.03 \\
(0.04)\end{array}$ & $\begin{array}{c}36.47 \\
(14.73)^{* *}\end{array}$ & $\begin{array}{c}17.28 \\
(17.30)\end{array}$ & $\begin{array}{l}-0.00 \\
(0.04)\end{array}$ & $\begin{array}{c}0.02 \\
(0.02)\end{array}$ & $\begin{array}{c}34.81 \\
(27.37)\end{array}$ \\
\hline $\mathrm{R}^{2}$ & 0.06 & 0.09 & 0.05 & 0.03 & 0.03 & 0.02 \\
\hline Matching & $\begin{array}{c}0.07 \\
(0.04)^{*}\end{array}$ & $\begin{array}{c}30.79 \\
(7.55)^{* * *}\end{array}$ & $\begin{array}{c}15.83 \\
(5.14)^{* * *}\end{array}$ & $\begin{array}{c}0.01 \\
(0.04)\end{array}$ & $\begin{array}{c}0.03 \\
(0.01)^{* *}\end{array}$ & $\begin{array}{c}46.16 \\
(20.75)^{* *}\end{array}$ \\
\hline \multicolumn{7}{|l|}{ Sons $(\mathrm{N}=549)$} \\
\hline OLS & $\begin{array}{c}0.16 \\
(0.13)\end{array}$ & $\begin{array}{c}40.07 \\
(21.66)^{*}\end{array}$ & $\begin{array}{c}33.46 \\
(24.62)\end{array}$ & $\begin{array}{c}0.09 \\
(0.04)^{* *}\end{array}$ & $\begin{array}{l}-0.00 \\
(0.03)\end{array}$ & $\begin{array}{c}23.18 \\
(36.63)\end{array}$ \\
\hline $\mathrm{R}^{2}$ & 0.13 & 0.19 & 0.15 & 0.10 & 0.18 & 0.24 \\
\hline Matching & $\begin{array}{c}0.38 \\
(0.10)^{* * *}\end{array}$ & $\begin{array}{c}48.84 \\
(17.81)^{* * *}\end{array}$ & $\begin{array}{c}13.08 \\
(16.23)\end{array}$ & $\begin{array}{c}0.09 \\
(0.06)\end{array}$ & $\begin{array}{c}0.02 \\
(0.05)\end{array}$ & $\begin{array}{c}11.69 \\
(42.39)\end{array}$ \\
\hline \multicolumn{7}{|l|}{ Daughters $(\mathrm{N}=394)$} \\
\hline OLS & $\begin{array}{c}0.15 \\
(0.15)\end{array}$ & $\begin{array}{c}23.98 \\
(18.59)\end{array}$ & $\begin{array}{c}17.42 \\
(20.48)\end{array}$ & $\begin{array}{l}-0.13 \\
(0.09)\end{array}$ & $\begin{array}{c}0.05 \\
(0.02)^{* *}\end{array}$ & $\begin{array}{c}29.62 \\
(21.15)\end{array}$ \\
\hline $\mathrm{R}^{2}$ & 0.13 & 0.24 & 0.15 & 0.17 & 0.25 & 0.43 \\
\hline Matching & $\begin{array}{l}-0.00 \\
(0.16)\end{array}$ & $\begin{array}{c}6.69 \\
(18.86)\end{array}$ & $\begin{array}{c}26.63 \\
(17.35)\end{array}$ & $\begin{array}{c}-0.15 \\
(0.06)^{* * *}\end{array}$ & $\begin{array}{c}0.03 \\
(0.02)\end{array}$ & $\begin{array}{l}1.08 \\
(0.77)\end{array}$ \\
\hline \multicolumn{7}{|l|}{ Male Heads/Spouses N=1,164) } \\
\hline OLS & $\begin{array}{c}-0.12 \\
(0.06)^{*}\end{array}$ & $\begin{array}{c}55.46 \\
(21.53)^{* *}\end{array}$ & $\begin{array}{c}17.30 \\
(23.97)\end{array}$ & $\begin{array}{c}0.02 \\
(0.06)\end{array}$ & $\begin{array}{c}0.06 \\
(0.04)\end{array}$ & $\begin{array}{c}33.09 \\
(81.96)\end{array}$ \\
\hline $\mathrm{R}^{2}$ & 0.12 & 0.11 & 0.05 & 0.06 & 0.04 & 0.05 \\
\hline Matching & $\begin{array}{c}-0.14 \\
(0.04)^{* * *}\end{array}$ & $\begin{array}{c}8.99 \\
(16.29)\end{array}$ & $\begin{array}{c}13.85 \\
(16.11)\end{array}$ & $\begin{array}{c}0.04 \\
(0.07)\end{array}$ & $\begin{array}{c}0.07 \\
(0.05)\end{array}$ & $\begin{array}{c}60.30 \\
(56.88)\end{array}$ \\
\hline \multicolumn{7}{|l|}{ Female Heads/Spouses $(\mathrm{N}=1,536)$} \\
\hline OLS & $\begin{array}{c}0.02 \\
(0.02)\end{array}$ & $\begin{array}{c}21.14 \\
(19.31)\end{array}$ & $\begin{array}{c}13.52 \\
(16.74)\end{array}$ & $\begin{array}{l}-0.00 \\
(0.06)\end{array}$ & $\begin{array}{c}0.01 \\
(0.01)\end{array}$ & $\begin{array}{c}54.69 \\
(29.85)^{*}\end{array}$ \\
\hline $\mathrm{R}^{2}$ & 0.08 & 0.09 & 0.06 & 0.04 & 0.05 & 0.05 \\
\hline Matching & $\begin{array}{c}0.02 \\
(0.03)\end{array}$ & $\begin{array}{c}-13.86 \\
(17.06)\end{array}$ & $\begin{array}{c}3.77 \\
(12.01)\end{array}$ & $\begin{array}{c}0.07 \\
(0.04)^{*}\end{array}$ & $\begin{array}{c}-0.02 \\
(0.01)^{* *}\end{array}$ & $\begin{array}{c}21.94 \\
(8.93)^{* *}\end{array}$ \\
\hline F test: Equality of coefficients & 2.00 & $2.61 *$ & 0.63 & 1.55 & 0.84 & 0.53 \\
\hline
\end{tabular}

Notes: $* * \mathrm{p}<0.01,{ }^{* *} \mathrm{p}<0.05, * \mathrm{p}<0.1$. See Table 2 notes for details on specifications. 
Table 6: Impacts of the Migration of a Head's Daughter, OLS and Matching Estimates for Ethiopia

(1)

(2)

(3)

(4)

(5)

(6)

$\begin{array}{cccccc}\begin{array}{c}\text { Works on } \\ \text { farm }\end{array} & \begin{array}{c}\text { Hours } \\ \text { planting }\end{array} & \begin{array}{c}\text { Hours } \\ \text { harvesting }\end{array} & \begin{array}{c}\text { Works in } \\ \text { enterprise }\end{array} & \begin{array}{c}\text { Works } \\ \text { wage } \\ \text { labor }\end{array} & \begin{array}{c}\text { Hours on } \\ \text { wage } \\ \text { labor }\end{array}\end{array}$

\begin{tabular}{|c|c|c|c|c|c|c|}
\hline \multicolumn{7}{|l|}{ Pooled $(\mathrm{N}=6,216)$} \\
\hline OLS & $\begin{array}{c}0.01 \\
(0.02)\end{array}$ & $\begin{array}{l}-18.62 \\
(23.35)\end{array}$ & $\begin{array}{c}19.95 \\
(12.58)\end{array}$ & $\begin{array}{l}-0.02 \\
(0.02)\end{array}$ & $\begin{array}{c}-0.02 \\
(0.01)^{*}\end{array}$ & $\begin{array}{c}13.77 \\
(19.00)\end{array}$ \\
\hline $\mathrm{R}^{2}$ & 0.31 & 0.39 & 0.37 & 0.10 & 0.11 & 0.06 \\
\hline Matching & $\begin{array}{c}-0.06 \\
(0.02)^{* * *}\end{array}$ & $\begin{array}{l}-16.51 \\
(19.91)\end{array}$ & $\begin{array}{c}-22.39 \\
(10.01)^{* *}\end{array}$ & $\begin{array}{c}-0.04 \\
(0.02)^{* *}\end{array}$ & $\begin{array}{l}-0.01 \\
(0.01)\end{array}$ & $\begin{array}{c}17.26 \\
(12.92)\end{array}$ \\
\hline \multicolumn{7}{|l|}{ Sons $(N=916)$} \\
\hline OLS & $\begin{array}{l}-0.00 \\
(0.05)\end{array}$ & $\begin{array}{l}-62.57 \\
(64.80)\end{array}$ & $\begin{array}{c}-1.31 \\
(30.34)\end{array}$ & $\begin{array}{c}0.01 \\
(0.06)\end{array}$ & $\begin{array}{l}-0.03 \\
(0.04)\end{array}$ & $\begin{array}{c}-16.44 \\
(27.77)\end{array}$ \\
\hline $\mathrm{R}^{2}$ & 0.37 & 0.55 & 0.46 & 0.30 & 0.39 & 0.32 \\
\hline Matching & $\begin{array}{c}0.03 \\
(0.06)\end{array}$ & $\begin{array}{c}29.37 \\
(42.41)\end{array}$ & $\begin{array}{c}50.98 \\
(21.48)^{* *}\end{array}$ & $\begin{array}{c}-0.13 \\
(0.05)^{* * *}\end{array}$ & $\begin{array}{c}0.01 \\
(0.02)\end{array}$ & $\begin{array}{c}38.71 \\
(17.03)^{* *}\end{array}$ \\
\hline \multicolumn{7}{|l|}{ Daughters $(\mathrm{N}=480)$} \\
\hline OLS & $\begin{array}{l}-0.08 \\
(0.11)\end{array}$ & $\begin{array}{c}-68.57 \\
(76.28)\end{array}$ & $\begin{array}{c}4.98 \\
(36.95)\end{array}$ & $\begin{array}{l}-0.07 \\
(0.08)\end{array}$ & $\begin{array}{c}0.01 \\
(0.04)\end{array}$ & $\begin{array}{c}48.74 \\
(84.92)\end{array}$ \\
\hline $\mathrm{R}^{2}$ & 0.49 & 0.67 & 0.59 & 0.50 & 0.44 & 0.46 \\
\hline Matching & $\begin{array}{c}0.01 \\
(0.09)\end{array}$ & $\begin{array}{c}10.09 \\
(38.87)\end{array}$ & $\begin{array}{c}13.99 \\
(28.44)\end{array}$ & $\begin{array}{c}0.13 \\
(0.05)^{* * *}\end{array}$ & $\begin{array}{c}-0.03 \\
(0.01)^{* * *}\end{array}$ & $\begin{array}{c}-38.46 \\
(17.18)^{* *}\end{array}$ \\
\hline \multicolumn{7}{|l|}{ Male Heads/Spouses $(\mathrm{N}=2,068)$} \\
\hline OLS & $\begin{array}{l}-0.01 \\
(0.02)\end{array}$ & $\begin{array}{l}-52.19 \\
(49.44)\end{array}$ & $\begin{array}{c}1.86 \\
(20.58)\end{array}$ & $\begin{array}{c}-0.06 \\
(0.03)^{* *}\end{array}$ & $\begin{array}{l}-0.04 \\
(0.03)\end{array}$ & $\begin{array}{c}27.93 \\
(58.01)\end{array}$ \\
\hline $\mathrm{R}^{2}$ & 0.57 & 0.60 & 0.54 & 0.24 & 0.21 & 0.15 \\
\hline Matching & $\begin{array}{c}-0.07 \\
(0.03)^{* *}\end{array}$ & $\begin{array}{c}-147.47 \\
(43.87)^{* * *}\end{array}$ & $\begin{array}{l}-21.38 \\
(18.28)\end{array}$ & $\begin{array}{c}-0.11 \\
(0.03)^{* * *}\end{array}$ & $\begin{array}{l}-0.04 \\
(0.02)\end{array}$ & $\begin{array}{c}39.30 \\
(27.94)\end{array}$ \\
\hline \multicolumn{7}{|l|}{ Female Heads/Spouses $(\mathrm{N}=2,752)$} \\
\hline OLS & $\begin{array}{c}0.02 \\
(0.03)\end{array}$ & $\begin{array}{c}5.31 \\
(23.68)\end{array}$ & $\begin{array}{c}33.57 \\
(13.23)^{* *}\end{array}$ & $\begin{array}{l}-0.00 \\
(0.02)\end{array}$ & $\begin{array}{l}-0.01 \\
(0.00)\end{array}$ & $\begin{array}{c}-1.54 \\
(11.62)\end{array}$ \\
\hline $\mathrm{R}^{2}$ & 0.40 & 0.50 & 0.48 & 0.13 & 0.18 & 0.20 \\
\hline Matching & $\begin{array}{l}-0.04 \\
(0.03)\end{array}$ & $\begin{array}{c}36.47 \\
(23.76)\end{array}$ & $\begin{array}{c}-8.05 \\
(16.40)\end{array}$ & $\begin{array}{l}-0.04 \\
(0.03)\end{array}$ & $\begin{array}{l}-0.01 \\
(0.00)\end{array}$ & $\begin{array}{l}-6.87 \\
(9.66)\end{array}$ \\
\hline F test: Equality of coefficients & 0.27 & 0.99 & 0.82 & 0.50 & 0.50 & 0.33 \\
\hline
\end{tabular}

Notes: ${ }^{* * *} \mathrm{p}<0.01,{ }^{* *} \mathrm{p}<0.05,{ }^{*} \mathrm{p}<0.1$. See Table 2 notes for details on specifications. 
Table 7: Impacts of the Migration of a Head's Daughter, OLS and Matching Estimates for Malawi

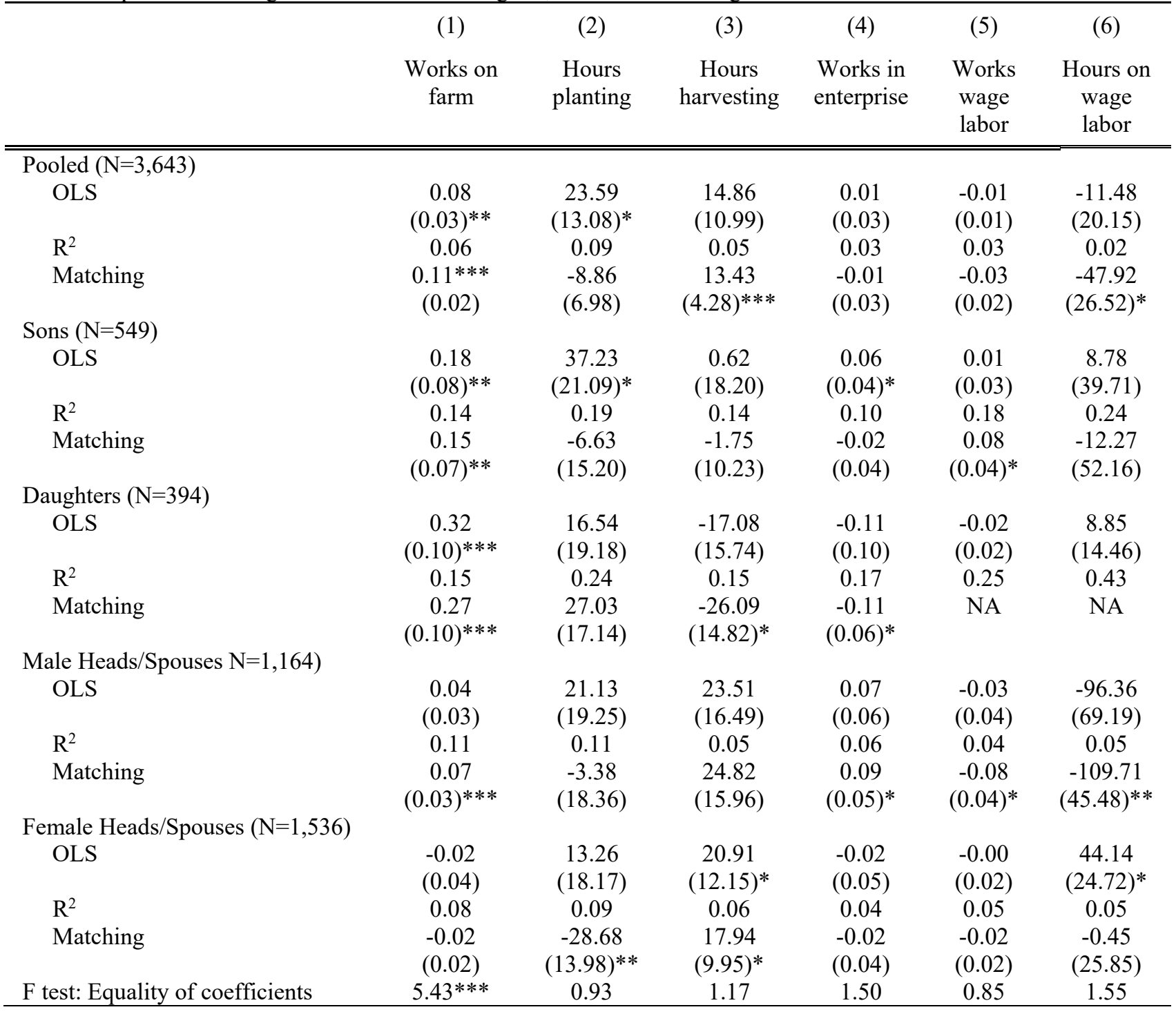


Table 8: Impacts of the Migration of a Head's Child to Urban Areas, OLS and Matching Estimates for Ethiopia

\begin{tabular}{|c|c|c|c|c|c|c|}
\hline & (1) & (2) & (3) & (4) & (5) & (6) \\
\hline & $\begin{array}{l}\text { Works } \\
\text { on farm }\end{array}$ & $\begin{array}{l}\text { Hours } \\
\text { planting }\end{array}$ & $\begin{array}{c}\text { Hours } \\
\text { harvesting }\end{array}$ & $\begin{array}{l}\text { Works in } \\
\text { enterprise }\end{array}$ & $\begin{array}{l}\text { Works } \\
\text { wage } \\
\text { labor }\end{array}$ & $\begin{array}{c}\text { Hours on } \\
\text { wage } \\
\text { labor }\end{array}$ \\
\hline \multicolumn{7}{|l|}{ Pooled $(\mathrm{N}=6,216)$} \\
\hline OLS & $\begin{array}{c}0.03 \\
(0.03)\end{array}$ & $\begin{array}{c}15.36 \\
(25.29)\end{array}$ & $\begin{array}{c}22.60 \\
(14.77)\end{array}$ & $\begin{array}{c}0.01 \\
(0.03)\end{array}$ & $\begin{array}{c}0.01 \\
(0.01)\end{array}$ & $\begin{array}{c}24.05 \\
(16.56)\end{array}$ \\
\hline $\mathrm{R}^{2}$ & 0.31 & 0.39 & 0.37 & 0.10 & 0.11 & 0.07 \\
\hline Matching & $\begin{array}{l}0.05^{*} \\
(0.03)\end{array}$ & $\begin{array}{c}8.55 \\
(22.96)\end{array}$ & $\begin{array}{c}8.49 \\
(10.02)\end{array}$ & $\begin{array}{l}-0.02 \\
(0.03)\end{array}$ & $\begin{array}{c}0.02 \\
(0.01)^{*}\end{array}$ & $\begin{array}{c}10.39 \\
(10.93)\end{array}$ \\
\hline \multicolumn{7}{|l|}{ Sons $(\mathrm{N}=916)$} \\
\hline OLS & $\begin{array}{c}0.01 \\
(0.08)\end{array}$ & $\begin{array}{c}24.42 \\
(144.40)\end{array}$ & $\begin{array}{c}62.83 \\
(37.48)^{*}\end{array}$ & $\begin{array}{c}0.01 \\
(0.06)\end{array}$ & $\begin{array}{c}0.04 \\
(0.04)\end{array}$ & $\begin{array}{c}32.86 \\
(34.66)\end{array}$ \\
\hline $\mathrm{R}^{2}$ & 0.37 & 0.55 & 0.47 & 0.30 & 0.39 & 0.32 \\
\hline Matching & $\begin{array}{c}0.12 \\
(0.05)^{* *}\end{array}$ & $\begin{array}{c}11.15 \\
(55.15)\end{array}$ & $\begin{array}{c}85.93 \\
(22.17)^{* * *}\end{array}$ & $\begin{array}{l}-0.00 \\
(0.04)\end{array}$ & $\begin{array}{c}0.08 \\
(0.04)^{* *}\end{array}$ & $\begin{array}{c}86.81 \\
(39.75)^{* *}\end{array}$ \\
\hline \multicolumn{7}{|l|}{ Daughters $(\mathrm{N}=480)$} \\
\hline OLS & $\begin{array}{l}-0.05 \\
(0.19)\end{array}$ & $\begin{array}{l}-117.52 \\
(111.65)\end{array}$ & $\begin{array}{l}-41.08 \\
(53.55)\end{array}$ & $\begin{array}{c}0.19 \\
(0.12)\end{array}$ & $\begin{array}{c}0.05 \\
(0.06)\end{array}$ & $\begin{array}{c}129.37 \\
(122.47)\end{array}$ \\
\hline $\mathrm{R}^{2}$ & 0.49 & 0.67 & 0.59 & 0.50 & 0.44 & 0.47 \\
\hline Matching & $\begin{array}{c}0.06 \\
(0.15)\end{array}$ & $\begin{array}{c}-34.15 \\
(53.62)\end{array}$ & $\begin{array}{c}28.89 \\
(43 / 04)\end{array}$ & $\begin{array}{c}0.29 \\
(0.12)\end{array}$ & $\begin{array}{c}0.02 \\
(0.02)\end{array}$ & $\begin{array}{c}20.01 \\
(10.33)^{*}\end{array}$ \\
\hline \multicolumn{7}{|l|}{ Male Heads/Spouses $(\mathrm{N}=2,068)$} \\
\hline OLS & $\begin{array}{c}0.03 \\
(0.03)\end{array}$ & $\begin{array}{l}-10.33 \\
(38.37)\end{array}$ & $\begin{array}{c}40.34 \\
(21.93)^{*}\end{array}$ & $\begin{array}{l}-0.04 \\
(0.04)\end{array}$ & $\begin{array}{c}0.04 \\
(0.03)\end{array}$ & $\begin{array}{c}37.90 \\
(41.02)\end{array}$ \\
\hline $\mathrm{R}^{2}$ & 0.57 & 0.60 & 0.54 & 0.24 & 0.21 & 0.15 \\
\hline Matching & $\begin{array}{c}0.00 \\
(0.04)\end{array}$ & $\begin{array}{c}-68.48 \\
(51.10)\end{array}$ & $\begin{array}{l}-19.78 \\
(22.96)\end{array}$ & $\begin{array}{c}-0.09 \\
(0.03)^{* * *}\end{array}$ & $\begin{array}{c}0.02 \\
(0.03)\end{array}$ & $\begin{array}{c}44.58 \\
(29.96)\end{array}$ \\
\hline \multicolumn{7}{|l|}{ Female Heads/Spouses $(\mathrm{N}=2,752)$} \\
\hline OLS & $\begin{array}{c}0.05 \\
(0.03)\end{array}$ & $\begin{array}{c}11.05 \\
(28.11)\end{array}$ & $\begin{array}{c}10.01 \\
(16.73)\end{array}$ & $\begin{array}{c}0.01 \\
(0.04)\end{array}$ & $\begin{array}{l}-0.01 \\
(0.01)\end{array}$ & $\begin{array}{c}-2.60 \\
(13.63)\end{array}$ \\
\hline $\mathrm{R}^{2}$ & 0.40 & 0.50 & 0.48 & 0.13 & 0.18 & 0.20 \\
\hline Matching & $\begin{array}{c}0.03 \\
(0.03)\end{array}$ & $\begin{array}{c}10.23 \\
(28.36)\end{array}$ & $\begin{array}{c}6.74 \\
(15.80)\end{array}$ & $\begin{array}{l}-0.03 \\
(0.03)\end{array}$ & $\begin{array}{c}0.00 \\
(0.00)\end{array}$ & $\begin{array}{c}12.41 \\
(7.00)^{*}\end{array}$ \\
\hline F test: Equality of coefficients & 0.34 & 0.04 & 0.25 & 1.19 & 0.86 & 0.46 \\
\hline
\end{tabular}

Notes: $* * * \mathrm{p}<0.01,{ }^{* *} \mathrm{p}<0.05,{ }^{*} \mathrm{p}<0.1$. See Table 2 notes for details on specifications. 
Table 9: Impacts of the Migration of a Head's Child to Urban Areas, OLS and Matching Estimates for Malawi
(1)
(2)
(3)
(4)
(5)
(6)

Works on Hours Hours Works in Works Hours on farm planting harvesting enterprise wage wage labor

\begin{tabular}{|c|c|c|c|c|c|c|}
\hline \multicolumn{7}{|l|}{ Pooled $(\mathrm{N}=3,643)$} \\
\hline OLS & $\begin{array}{c}0.14 \\
(0.05)^{* *}\end{array}$ & $\begin{array}{c}7.36 \\
(18.39)\end{array}$ & $\begin{array}{c}10.37 \\
(16.46)\end{array}$ & $\begin{array}{c}-0.11 \\
(0.05)^{* *}\end{array}$ & $\begin{array}{l}-0.01 \\
(0.03)\end{array}$ & $\begin{array}{c}54.28 \\
(39.44)\end{array}$ \\
\hline $\mathrm{R}^{2}$ & 0.06 & 0.08 & 0.05 & 0.04 & 0.03 & 0.02 \\
\hline Matching & $\begin{array}{c}0.16 \\
(0.05)^{* * *}\end{array}$ & $\begin{array}{c}26.61 \\
(11.93)^{* *}\end{array}$ & $\begin{array}{c}20.37 \\
(5.43)^{* * *}\end{array}$ & $\begin{array}{c}-0.11 \\
(0.05)^{* *}\end{array}$ & $\begin{array}{c}-0.04 \\
(0.02)^{*}\end{array}$ & $\begin{array}{c}63.87 \\
(22.63)^{* * *}\end{array}$ \\
\hline \multicolumn{7}{|l|}{ Sons $(N=549)$} \\
\hline OLS & $\begin{array}{c}0.20 \\
(0.13)\end{array}$ & $\begin{array}{c}10.15 \\
(30.25)\end{array}$ & $\begin{array}{l}-13.36 \\
(17.62)\end{array}$ & $\begin{array}{c}0.02 \\
(0.06)\end{array}$ & $\begin{array}{l}-0.02 \\
(0.03)\end{array}$ & $\begin{array}{c}30.63 \\
(49.43)\end{array}$ \\
\hline $\mathrm{R}^{2}$ & 0.13 & 0.18 & 0.14 & 0.09 & 0.18 & 0.24 \\
\hline Matching & $\begin{array}{c}0.23 \\
(0.12)^{*}\end{array}$ & $\begin{array}{l}-39.25 \\
(24.35)\end{array}$ & $\begin{array}{l}-17.05 \\
(17.56)\end{array}$ & $\begin{array}{l}-0.05 \\
(0.07)\end{array}$ & $\begin{array}{c}-0.12 \\
(0.06)^{* *}\end{array}$ & $\begin{array}{c}-27.64 \\
(12.68)^{* *}\end{array}$ \\
\hline \multicolumn{7}{|l|}{ Daughters $(\mathrm{N}=394)$} \\
\hline OLS & $\begin{array}{c}0.44 \\
(0.14)^{* * *}\end{array}$ & $\begin{array}{c}51.24 \\
(19.67)^{* *}\end{array}$ & $\begin{array}{c}16.31 \\
(24.78)\end{array}$ & $\begin{array}{l}-0.16 \\
(0.11)\end{array}$ & $\begin{array}{c}0.00 \\
(0.02)\end{array}$ & $\begin{array}{c}8.60 \\
(12.24)\end{array}$ \\
\hline $\mathrm{R}^{2}$ & 0.16 & 0.25 & 0.15 & 0.18 & 0.25 & 0.43 \\
\hline Matching & $\begin{array}{l}-0.11 \\
(0.19)\end{array}$ & $\begin{array}{c}31.71 \\
(17.24)^{*}\end{array}$ & $\begin{array}{l}-15.40 \\
(17.63)\end{array}$ & $\begin{array}{c}-0.13 \\
(0.07)^{*}\end{array}$ & NA & NA \\
\hline \multicolumn{7}{|l|}{ Male Heads/Spouses $\mathrm{N}=1,164$ ) } \\
\hline OLS & $\begin{array}{l}-0.03 \\
(0.06)\end{array}$ & $\begin{array}{c}2.23 \\
(18.61)\end{array}$ & $\begin{array}{c}23.36 \\
(25.17)\end{array}$ & $\begin{array}{l}-0.07 \\
(0.07)\end{array}$ & $\begin{array}{c}0.08 \\
(0.07)\end{array}$ & $\begin{array}{c}102.51 \\
(116.58)\end{array}$ \\
\hline $\mathrm{R}^{2}$ & 0.11 & 0.11 & 0.05 & 0.06 & 0.04 & 0.05 \\
\hline Matching & $\begin{array}{c}0.06 \\
(0.06)\end{array}$ & $\begin{array}{c}6.34 \\
(27.61)\end{array}$ & $\begin{array}{c}3.18 \\
(22.90)\end{array}$ & $\begin{array}{l}-0.07 \\
(0.11)\end{array}$ & $\begin{array}{l}-0.01 \\
(0.07)\end{array}$ & $\begin{array}{c}126.69 \\
(74.66)^{*}\end{array}$ \\
\hline \multicolumn{7}{|c|}{ Female Heads/Spouses $(\mathrm{N}=1,536)$} \\
\hline OLS & $\begin{array}{c}0.03 \\
(0.03)\end{array}$ & $\begin{array}{l}-14.40 \\
(30.44)\end{array}$ & $\begin{array}{c}10.34 \\
(17.74)\end{array}$ & $\begin{array}{c}-0.15 \\
(0.07)^{* *}\end{array}$ & $\begin{array}{l}-0.06 \\
(0.05)\end{array}$ & $\begin{array}{c}100.35 \\
(58.53)^{*}\end{array}$ \\
\hline $\mathrm{R}^{2}$ & 0.08 & 0.09 & 0.06 & 0.05 & 0.05 & 0.05 \\
\hline Matching & $\begin{array}{c}0.03 \\
(0.02)\end{array}$ & $\begin{array}{l}-20.27 \\
(25.45)\end{array}$ & $\begin{array}{c}-4.09 \\
(16.89)\end{array}$ & $\begin{array}{c}-0.10 \\
(0.06)^{*}\end{array}$ & $\begin{array}{c}-0.10 \\
(0.04)^{* *}\end{array}$ & $\begin{array}{c}80.57 \\
(37.60)^{* *}\end{array}$ \\
\hline F test: Equality of coefficients & $5.65 * * *$ & $3.27 * *$ & 0.71 & 1.31 & $2.25 *$ & 0.71 \\
\hline
\end{tabular}

Notes: $* * * \mathrm{p}<0.01,{ }^{* *} \mathrm{p}<0.05,{ }^{*} \mathrm{p}<0.1$. See Table 2 notes for details on specifications. 
(2)

(3)

(4)

(5)

(6)

\begin{tabular}{|c|c|c|c|c|c|c|}
\hline & $\begin{array}{l}\text { Hired } \\
\text { labor }\end{array}$ & $\begin{array}{l}\text { Agricultural } \\
\text { profit }\end{array}$ & $\begin{array}{l}\text { Total } \\
\text { profit }\end{array}$ & $\begin{array}{l}\text { Hired } \\
\text { labor }\end{array}$ & $\begin{array}{l}\text { Agricultural } \\
\text { profit }\end{array}$ & $\begin{array}{l}\text { Total } \\
\text { profit }\end{array}$ \\
\hline \multicolumn{7}{|l|}{ Has a migrant child } \\
\hline OLS & $\begin{array}{l}-0.03 \\
(0.04)\end{array}$ & $\begin{array}{c}524.38 \\
(189.61)^{* * *}\end{array}$ & $\begin{array}{c}987.45 \\
(389.14)^{* *}\end{array}$ & $\begin{array}{c}0.17 \\
(0.05)^{* * *}\end{array}$ & $\begin{array}{l}-17.16 \\
(48.98)\end{array}$ & $\begin{array}{l}-133.70 \\
(188.62)\end{array}$ \\
\hline $\mathrm{R}^{2}$ & 0.26 & 0.51 & 0.48 & 0.06 & 0.15 & 0.08 \\
\hline Matching & $\begin{array}{l}-0.01 \\
(0.03)\end{array}$ & $\begin{array}{c}159.82 \\
(185.55)\end{array}$ & $\begin{array}{c}314.82 \\
(289.15)\end{array}$ & $\begin{array}{c}0.17 \\
(0.05)^{* * *}\end{array}$ & $\begin{array}{c}5.51 \\
(42.51)\end{array}$ & $\begin{array}{c}5.84 \\
(225.78)\end{array}$ \\
\hline \multicolumn{7}{|l|}{ Has a migrant son } \\
\hline OLS & $\begin{array}{l}-0.05 \\
(0.05)\end{array}$ & $\begin{array}{c}662.30 \\
(252.03)^{* * *}\end{array}$ & $\begin{array}{l}1,310.76 \\
(523.46)^{* *}\end{array}$ & $\begin{array}{c}0.20 \\
(0.07)^{* * *}\end{array}$ & $\begin{array}{l}-96.13 \\
(76.65)\end{array}$ & $\begin{array}{l}-491.53 \\
(308.47)\end{array}$ \\
\hline $\mathrm{R}^{2}$ & 0.26 & 0.51 & 0.48 & 0.06 & 0.15 & 0.08 \\
\hline Matching & $\begin{array}{l}-0.04 \\
(0.04)\end{array}$ & $\begin{array}{c}331.54 \\
(256.08)\end{array}$ & $\begin{array}{c}935.61 \\
(390.20)^{* *}\end{array}$ & $\begin{array}{c}0.23 \\
(0.07)^{* * *}\end{array}$ & $\begin{array}{c}-149.69 \\
(105.30)^{* *}\end{array}$ & $\begin{array}{l}-354.79 \\
(240.12)\end{array}$ \\
\hline \multicolumn{7}{|l|}{ Has a migrant daughter } \\
\hline OLS & $\begin{array}{l}-0.02 \\
(0.05)\end{array}$ & $\begin{array}{l}306.68 \\
(208.71)\end{array}$ & $\begin{array}{l}468.04 \\
(362.23)\end{array}$ & $\begin{array}{c}0.17 \\
(0.06)^{* * *}\end{array}$ & $\begin{array}{l}23.89 \\
(48.06)\end{array}$ & $\begin{array}{c}88.63 \\
(199.12)\end{array}$ \\
\hline $\mathrm{R}^{2}$ & 0.26 & 0.51 & 0.47 & 0.06 & 0.15 & 0.08 \\
\hline Matching & $\begin{array}{c}0.01 \\
(0.03)\end{array}$ & $\begin{array}{c}168.97 \\
(234.11)\end{array}$ & $\begin{array}{c}7.17 \\
(377.26)\end{array}$ & $\begin{array}{c}0.18 \\
(0.06)^{* * *}\end{array}$ & $\begin{array}{c}64.47 \\
(47.22)\end{array}$ & $\begin{array}{c}132.67 \\
(306.85)\end{array}$ \\
\hline $\begin{array}{l}\text { Has a rural-urban migrant chil } \\
\text { OLS }\end{array}$ & $\begin{array}{l}-0.04 \\
(0.05)\end{array}$ & $\begin{array}{c}593.90 \\
(233.10)^{* *}\end{array}$ & $\begin{array}{c}1,083.58 \\
(496.67)^{* *}\end{array}$ & $\begin{array}{c}0.20 \\
(0.12)\end{array}$ & $\begin{array}{c}88.04 \\
(72.02)\end{array}$ & $\begin{array}{c}43.72 \\
(460.34)\end{array}$ \\
\hline $\begin{array}{l}\mathrm{R}^{2} \\
\text { Matching }\end{array}$ & $\begin{array}{c}0.26 \\
-0.02 \\
(0.04)\end{array}$ & $\begin{array}{c}0.51 \\
278.24 \\
(285.27)\end{array}$ & $\begin{array}{c}0.47 \\
738.03 \\
(404.61)^{*}\end{array}$ & $\begin{array}{c}0.06 \\
0.30 \\
(0.12)^{* *}\end{array}$ & $\begin{array}{c}0.15 \\
162.30 \\
(76.38)^{*}\end{array}$ & $\begin{array}{c}0.08 \\
-382.53 \\
(501.47)\end{array}$ \\
\hline Mean of outcome at baseline & 0.19 & 364.73 & 593.19 & 0.37 & 333.42 & $1,201.52$ \\
\hline Mean change of outcome & 0.07 & $2,302.68$ & $3,059.48$ & -0.09 & -143.16 & -519.36 \\
\hline
\end{tabular}

Notes: $* * * \mathrm{p}<0.01, * * \mathrm{p}<0.05, * \mathrm{p}<0.1$. Outcomes are the change in the hired labor dummy and total net income (USD 2012) at the household level. Specifications are similar to Table 2 with the exception that individual covariates are dropped given the unit of analysis is the household. 


\section{END NOTES}

${ }^{1}$ We thank Xiaoya Dou and Mekamu Jedir Jamal for excellent research assistance. Our manuscript has benefitted from helpful discussions with Paul Christian and Emily Schmidt. We thank Fantu Bachewe and Bart Minten for sharing the Ethiopian wage data presented in this paper. Finally, this paper has benefitted from the support provided by the CGIAR Research Program on Policies, Institutions, and Markets (PIM) led by the International Food Policy Research Institute (IFPRI). Data and dofiles for the analysis are available upon request from the corresponding author.

${ }^{2}$ The focus in this paper is the role of youth internal migration, but there are strong differences in the international migration patterns across contexts as well. For example, Ethiopians travel to the Middle East (de Brauw et al., 2013a) and Malawians tend to gravitate toward South Africa and Zimbabwe (Lewin et al., 2012).

${ }^{3}$ It should be noted that the evolution of migration patterns may ultimately have more dynamic impacts on structural transformation in developing countries which are left unexplored here due to data constraints. First, if educated sons move because of land scarcity or concerns over underemployment and if children who are left behind compensate for the shortfall in labor, a lack of human capital in rural areas may stymie advancements in agriculture. Second, remittance income may change who controls income within the household. While remittances have the potential to increase investment in agriculture, depending on the profile of the decisionmaker, they may also be spent on alternative physical or human capital investments. If women favor human capital investments (Mueller et al., 2015), we might observe a disinvestment in agriculture rather than farm expansions and increased investments in modern technologies. Data covering a longer timeframe 
would be more fruitful to explore these long-term impacts of migration on human and physical capital investments and future farming systems.

${ }^{4}$ Household attrition of the overall (rural and urban) sample is rather low (5 percent in Ethiopia, and 4 percent in Malawi) over the two year period (NSO, 2014; CSA and World Bank, 2015).

${ }^{5}$ Table 1 shows that there are noticeable positive changes on average in the inherited land variable both countries, driven by the death of a family member.

${ }^{6}$ This information was collected using different protocols in each country. In Ethiopia, the information is constructed based on self-reported information by the proxy respondent (often the head of household). Despite the careful documentation of each household member in the baseline household roster, revealing or recalling the nature of the member's absence is at the discretion of the household head, making the household member's mobility status subject to measurement error. In Malawi, the migration definition is verified by the migrant at their destination at endline. While the tracking protocol offers precision in Malawi, a minority of migrants were unsuccessfully tracked (6 percent) and therefore are omitted from the analysis (NSO, 2014). These limitations in the measurement of migration are not unique to this study.

${ }^{7}$ Migration distance is only available in Malawi, where migrants were tracked and georeferenced. Lee and Mueller (2016) find young (ages 15 to 24) rural-rural migrants tend to travel over one kilometer relative to rural-urban migrants who travel approximately 60 kilometers.

${ }^{8}$ We may underreport the number of family members employed in the household's nonfarm enterprise in both countries. The Ethiopia survey documents at most five people hired in the enterprise, while the Malawi survey asks for the identification of at most two household members who manage and two household members who own the enterprise. A total of four or less household members may be included in the Malawi data. 
${ }^{9}$ Values are winsorized at one percent to reduce the influence of outliers.

${ }^{10}$ The discrepancy in time frames is due to differences in the survey instrument. In Ethiopia, the labor questions are asked over the current season, while in Malawi, the labor questions are asked over the two seasons.

${ }^{11}$ The migration of family members is dominated by the children of the heads in both Ethiopia and Malawi. Twenty-five (27) percent of sons and 38 (37) percent of daughters in Ethiopia (Malawi) moved by the follow up round. While the mobility of heads and their spouses in Malawi exceeds that of Ethiopia (13 percent compared to 2 percent), the younger generation is much more mobile. ${ }^{12}$ Our final list of towns/cities is 25 in Ethiopia and 4 in Malawi.

${ }^{13}$ Wage growth is converted into 2011 real terms in both Ethiopia and Malawi using consumer price indices (CSA, 2013b; NSO, 2016).

${ }^{14}$ Busso, di Nardo, and McCary (2014) recommend the use of the nearest neighbor matching approach with bias-correction in lieu of other reweighting or matching estimators particularly when the overlap is poor. We estimate the distribution of the propensity scores based on our covariates of interest to find overlap may be imperfect (Figures A.1- A.2).

15 Tables A.4 and A.5 model these migration decisions using probit regressions. The covariates are sufficiently strong determinants of the migration of sons in Malawi. Inherited land becomes a significant explanatory variable when evaluating the probability of someone in the pooled sample having a child of the household move to an urban area. This finding supports conventional wisdom regarding migration driven by land scarcity in Ethiopia (de Brauw and Mueller, 2012).

${ }^{16}$ Few observations in our sample live in households that either have a head or spouse that migrates or an additional member that moves internationally. To assuage concerns that our estimates are driven by the inclusion of these few occurrences, we present the matching results for the employed 
on the farm outcomes dropping observations in households with head/spouse migrants and internationally migrants in Table A.6.

${ }^{17}$ Bias-corrected matching estimates are the same irrespective of the number of matches used (not shown here). Trimmed sample matching estimates are qualitatively similar as to those using the entire sample (Tables A.7 and A.8).

${ }^{18}$ Interestingly, there is weaker evidence to suggest a greater percentage of daughters are tasked with working in the nonfarm enterprise when a head's son migrates in Ethiopia. The order of magnitude far exceeds the percentage point increase in female adults called to work on the farm. Because our $\mathrm{F}$ tests do not support that these effects statistically differ from those observed among other family members, the figures are merely suggestive that daughters may also substitute for sons who spend more time on the farm during the harvesting period.

${ }^{19}$ Agricultural and total profit are reported in 2012 US dollars and winsorized at 5 percent. Total income includes agricultural revenue net input expenditures, non-farm enterprise revenue net input costs, wage income, and transfers. 


\section{References}

Abadie, A., Drukker, D., Herr, J. \& Imbens, G. (2004). Implementing Matching Estimators for Average Treatment Effects in Stata. The Stata Journal 4, 290-311.

Abadie, A. \& Imbens, G. (2008). On the failure of the bootstrap for matching estimators. Econometrica 76, 1537-1557.

Aguilar, A., Carranza, E., Goldstein, M., Kilic, T., \& Oseni, G. (2015). Decomposition of Gender Differentials in Agricultural Productivity in Ethiopia. Agricultural Economics 46, 311-334.

Beegle, K., De Weerdt, J., \& Dercon, S. (2011). Migration and Economic Mobility in Tanzania. The Review of Economics and Statistics 93, 1010-1033.

Bevan, P., \& Pankhurst, A. (Eds.) (1996). Fifteen Ethiopian Village Studies. Oxford University and Addis Ababa University.

Busso, M., DiNardo, J., \& McCrary, J. (2014). New evidence on the finite sample properties of propensity score reweighting and matching estimators., Review of Economics and Statistics $96,885-897$.

Central Statistical Agency (CSA) (2013a). Country and Regional Level Consumer Price Indices. Addis Ababa, Federal Democratic Republic of Ethiopia.

Central Statistical Agency (CSA) (2013b). Consumer Price Survey. Addis Ababa, Federal Democratic Republic of Ethiopia.

Central Statistical Authority (CSA) and World Bank (2015). Ethiopia Socioeconomic Survey (ESS) 
Wave Two (2013/2014): Basic Information Document. Downloaded online on April 25, 2016 at: http://siteresources.worldbank.org/INTLSMS/Resources/3358986$\underline{1233781970982 / 5800988-1367841456879 / 9170025-}$ 1427144247562/Basic_Information_Document_Wave_2.pdf.

Climate Hazards Group (CHG) (2016). Climate Hazards Group InfraRed Precipitation with Station data, monthly time-series 1982-2014. Accessed online January 15, 2016 at: http://chg.geog.ucsb.edu/data/chirps/.

Croppenstedt, A., Goldstein, M., \& Rosas, N. (2013). Gender and Agriculture: Inefficiencies, Segregation, and Low Productivity Traps. World Bank Research Observer 28, 79-109. de Brauw, A., Huang, J., Zhang, L., \& Rozelle, S. (2013b). The Feminization of Agriculture with Chinese Characteristics. Journal of Development Studies 49, 689-704.

de Brauw, A., Li, Q., Chengfang, L., Rozelle, S., \& Zhang, L. (2008). Feminization of Agriculture in China? Myths Surrounding Women's Participation in Farming. China Quarterly 194, 327-348.

de Brauw, A. \& Mueller, V. (2012). Do Limitations in Land Rights Transferability Influence Low Mobility Rates in Ethiopia? Journal of African Economies 21, 548-579. de Brauw, A., Mueller, V., \& Lee, H. L. (2014). The Role of Rural-Urban Migration in the Structural Transformation of sub-Saharan Africa. World Development 63, 33-42. de Brauw, A., Mueller, V., \& Woldehanna, T. (2017). Does Internal Migration Improve Overall Well-Being in Ethiopia?” Journal of African Economies. https://doi.org/10.1093/jae/ejx026.

Dillon, A., Mueller, V., \& Salau, S. (2011). Migratory Responses to Agricultural Risk in Northern Nigeria. American Journal of Agricultural Economics 93, 1048-1061. 
Dinkelman, T., Kumchulesi, G., \& Mariotti, M. (2015). Labor migration and the Structure of Rural Labor Markets. Unpublished manuscript, Department of Economics, Dartmouth College, Hanover, New Hampshire.

Doss, C. (2002). Men's crops? Women's crops? The gender patterns of cropping in Ghana. World Development 30, 1987-2000.

Fafchamps, M. \& Quisumbing, A. (2002). Control and Ownership of Assets within Rural Ethiopian Households. Journal of Development Studies 38, 47-82.

Holden, S., Shiferaw, B., \& Pender, J. (2001). Market Imperfections and Land Productivity in the Ethiopian Highlands. Journal of Agricultural Economics 52, 53-70.

Kilic, T., Palacios-Lopez, A., \& Goldstein, M. (2015). Caught in a Productivity Trap: A Distributional Perspective on Gender Differences in Malawian Agriculture. World Development 70, 416-463.

Lee, H.L., \& Mueller, V. (2016). Can Migration Be A Conduit for Transformative Youth Employment? Evidence from the LSMS-ISA Countries? Unpublished manuscript. Development Strategy and Governance Division, International Food Policy Research Institute, Washington, D.C.

Lokshin, M. \& Glinskaya, E. (2009). The Effect of Male Migration on Employment Patterns of Women in Nepal. World Bank Economic Review 23, 481-507.

Lucas, R. E. B. (2015). African Migration. In B. Chiswick \& P. Miller (Eds.) The Handbook of the Economics of International Migration (volume 1B). Amsterdam, Holland: Elsevier. McKenzie, D., Stillman, S., \& Gibson, J. (2010). How Important is Selection? Experimental vs. Non-Experimental Measures of the Income Gains from Migration. Journal of the European Economic Association 8, 913-945. 
Moller, L. C. (2012). The Ethiopian Urban Migration Study 2008: The Characteristics, Motives and Outcomes to Immigrants to Addis Ababa. Washington, D.C.: World Bank Group.

Mueller, V., Schmidt, E., Lozano-Gracia, N., \& Murray, S. (2016). Household and Spatial Drivers of Migration Patterns in Africa: Evidence from Four Countries. Paper prepared for the Structural Transformation of African Agriculture and Rural Spaces (STAARS) conference 2015, Addis Ababa, Ethiopia.

Mueller, V., Kovarik, C., Sproule, K., \& Quisumbing, A. (2015). Migration, Gender, and Farming Systems in Asia: Evidence, Data, and Knowledge Gaps. International Food Policy Research Institute Discussion Paper No. 1458.

National Statistical Office (NSO) (2016). Consumer Price Index Rural. Downloaded online on April 26, 2016 at: http://www.nsomalawi.mw/latest-publications/consumer-price-indices/69consumer-price-index-rural.html.

National Statistical Office (NSO) (2014). Malawi Integrated Household Panel Survey 2013: Basic Information Document. Downloaded online on April 25, 2016 at: http://siteresources.worldbank.org/INTLSMS/Resources/3358986$\underline{1233781970982 / 5800988-1271185595871 / 6964312-}$ 1404828635943/IHPS_BID_FINAL.pdf.

Pankhurst, R. (1990). A Social History of Ethiopia. Addis Ababa: Institute of Ethiopian Studies, Addis Ababa University.

Pankhurst, A., Dessalegn, M., Mueller, V., \& Hailemariam, N. (2013). Migration and Resettlement in Ethiopia: Reflections on Trends and Implications for Food Security. In A. Pankhurst, D. Rahmato, \& G. Van Uffelen (Eds.), Food Security, Safety Nets and Social Protection: the Ethiopian Experience. Addis Ababa, Ethiopia: Forum for Social Studies. 
Peters, P. (1990). Our Daughters Inherit Our Land, but Our Sons Use Their Wives’ Fields:

Matrilineal-Matrilocal Land Tenure and the New Land Policy in Malawi. Journal of Eastern African Studies 4, 179-199.

Potts, D. (2006). Rural Mobility as a Response to Land Shortages: the case of Malawi. Population, Space and Place 12, 291-311.

Rahmato, D. (1991) Rural Women in Ethiopia: Problems and prospects. In T. Berhane-Selassie (Ed.), Gender Issues in Ethiopia, Addis Ababa, Ethiopia: Institute of Ethiopian Studies, Addis Ababa University.

Rose, E., (2001). Ex Ante and Ex Post Labor Supply Responses to Risk in a Low Income Area. Journal of Development Economics 64, 371-388.

Thomas, K. \& Inkpen, C. (2013). Migration Dynamics, Entrepreneurship, and African Development: Lessons from Malawi. International Migration Review 47, 844-873.

Webb, P., von Braun, J., \& Yohannes, Y. (1992). Famine in Ethiopia: Policy Implications of Coping Failure at National and Household Levels. International Food Policy Research Institute Research Report 92. Washington, D.C., USA: International Food Policy Research Institute.

World Bank (2016a). Living Standards Measurement Study_-Integrated Surveys on Agriculture, Ethiopia. Available online at: http://go.worldbank.org/HWKE6FXHJ0.

World Bank (2016b). Living Standards Measurement Study_-Integrated Surveys on Agriculture, Malawi. Available online at: http://go.worldbank.org/ZIWEL8UHQ0. 